\title{
Analysis of the comprehensive management of sewage sludge in Poland
}

\author{
Grzegorz Przydatek $^{1}\left[\right.$ [ $\cdot$ Aldona Katarzyna Wota ${ }^{1}$
}

Received: 27 August 2018 / Accepted: 9 September 2019 / Published online: 31 October 2019

(c) The Author(s) 2019

\begin{abstract}
The methods of sewage sludge management in Poland have largely been determined by the legal requirements related to the Poland's membership in the European Union. Since 1st January 2016, sewage sludge landfilling is prohibited. It must be emphasised that legal changes regarding wastewater management, along with the systematic increase in the volume of produced sludge, entail the necessity to change the existing method of sewage sludge management. This paper contains an analysis of solutions for management of sewage sludge produced in Poland over the period of 8 years. The goal of the work was an assessment of comprehensive management of sewage sludge produced in Poland from 2009 to 2016. Despite the decrease in the agricultural use of sewage sludge, their average share of $32 \%$ was the highest among other forms of sewage sludge management in Poland. Another form, related with the final stage of sewage sludge management, concerned its thermal processing. It was treated as a promising method, with a $19 \%$ increase over the analysed period. An optimal solution should be found to ensure safe management of sewage sludge.
\end{abstract}

Keywords Sewage sludge $\cdot$ Wastewater treatment plant $\cdot$ Degraded land reclamation $\cdot$ Sewage sludge incineration $\cdot$ Natural use of sewage sludge

\section{Introduction}

The chemical and biological composition of sewage sludge determines the method of disposal [1], while its composition depends on the content of contaminants in wastewater, as well as sewage treatment technology [2].

The volume of sewage sludge produced in the world, that must be managed in a safe manner for the environment, is rapidly increasing [3]. On this basis, the member states of the European Union were obliged to implement the sewage sludge Directive 86/278/EW of 12 June 1986. According to this directive, the use of sludge in agriculture is prohibited if the concentration of heavy metals exceeds certain limit values. The directive calls for the use of treated sludge, but it does not specify processing operations [4].

Another regulation, Directive 2000/60/EC, of the European Parliament and Council of Europe was adopted on 23

Grzegorz Przydatek

gprzydatek@pwsz-ns.edu.pl

1 Engineering Institute, State University of Applied Sciences in Nowy Sacz, Zamenhofa 1a Street, 33-300 Nowy Sącz, Poland
October 2000 and set the norms of joint community action in the field of water policy [5]. The Water Framework Directive defines sludge not as waste material, but as a 'product' of sewage treatment.

In turn, Directive 91/271/EEC, adopted on 21 May 1991, concerns the treatment of municipal sewage and is the operational directive [6]. This directive obliges managers to monitor and report municipal sewage treatment and the final disposal of municipal sewage sludge for agglomerations. Sewage sludge is also the subject of European Parliament and Council Directive (2008)/98/EC of 19 November 2008 on waste, which is the Waste Framework Directive that regulates recycling of wastes, including sewage sludge. The directive states that the prevention of waste production is the first priority. The second is the preparation of waste for reuse, recycling, or other forms of recovery, and finally, waste disposal. It is not possible to avoid the production of sewage sludge. Therefore, other steps of dealing with this specific waste are very important (i.e. preparation for reuse, understood as sludge reprocessing, including possible energy recovery or organic recycling) [7]. Limits regarding storing sewage sludge were introduced by Directive 99/31/ EC of 26 April 1999, called the Landfill Directive [8]. 
Alternative configurations for sludge management include mesophilic and thermophilic anaerobic digestion and composting, incineration, gasification and supercritical water oxidation. The global warming potential and the annual cash flow of each alternative are used to estimate a composite indicator for each alternative. According to Garrido-Baserba et al. [9], stakeholder preferences are integrated into the assessment through the development of scenarios prioritising economic or environmental aspects.

A successful strategy for sewage sludge management in the EU includes two major principal trends. The first one is the production of heat and electricity (made from biogas) as specific products that have renewable potential. The second trend is to treat the bio-solids as products, in which the sewage sludge is a major component. Sustainable development of sewage sludge procedures include (1) maximising the sludge recycle/recovery benefits through renewable energydependent systems and (2) developing innovative technologies and management systems, which are appropriate for local environmental conditions, including geo-economy, climate, etc. [10].

The nature of incoming sewage treatment plants and technological processes in sewage treatment plants determines the physicochemical properties of sewage sludge. In Poland, the content of organic compounds susceptible to biological degradation varies within wide limits from about $70 \%$ $\mathrm{dm}$ in crude sediments to $45-55 \% \mathrm{dm}$ in digestate sludges. The most important harmful organic compounds present in sediments include, among others, polycyclic aromatic hydrocarbons (PAHs), polychlorinated biphenyls (PCBs), polychlorinated dibenzodioxins and dibenzofurans (PCDD/ Fs), adsorbed organic chlorine compounds (AOXs) and pesticides [11].

A critical issue in the management of sewage sludge is the recognition of their environmental and social influences. Environmental sewage sludge management issues related to the recycling of sewage sludge on land include the risk of nutrient leaching, effects on soil biodiversity and greenhouse gas emissions. The environmental effects of a sludge line are dependent on the way the processes of management are implemented with each other [12]. The initial assessment in the aspect of the social influence of sewage sludge includes human health benefits from the reduced application and human health costs from alternative routes of disposal (e.g., air pollution from incineration and odour or amenity effects) [13].

Sewage sludge management is one of the significant challenges of wastewater management [14] and is one of the most important environmental problems in Poland [15]. In Poland, such activities have been included in the National Urban Wastewater Treatment Programme (NUWTP) approved on 16 December 2003, which outlines the state policy in wastewater management [16]. The NUWTP is a strategic document, coordinating the fulfilment of obligations assumed by Poland in the accession treaty of the 91/271/EEC directive [6]. The programme contains a list of necessary undertakings that must be carried out within the scope of construction and modernisation of wastewater treatment plants or collective sewage systems. In Poland, management of urban sewage sludge is regulated by the waste management act [17]. In the first place, sewage sludge must be processed at the site of origin, considering the hierarchy of waste treatment methods, using the best available technique. One of the final methods of sewage sludge management, including biological processing methods, is recovery, which is reuse of sludge (in various forms of processing) in restoring or giving new properties to the degraded. In the hierarchy of waste management, the final stage aims at neutralisation of sludge, which includes incineration and landfilling. The incineration is the most popular sludge disposal method in Europe [18], allowing to reduce its volumes.

In turn, sewage sludge landfilling is a process that has a significant impact on global warming [3]. Taking into account the increasingly stringent laws of the design and operation of new landfills [8], as well as the rapidly increasing costs of construction and operation of landfills [19], the amount of sewage sludge being stored is decreasing. Another factor limiting this form of sewage sludge disposal is the requirement that the landfilling must be reduced to $35 \%$ of biodegradable content by 2020 [20].

The goal of the work was an assessment of comprehensive management of sewage sludge produced in Poland from 2009 to 2016.

\section{Materials and methods}

This paper contains an analysis of sewage sludge management in Poland based on the statistical data (from 2009 to 2016) [21]. The analysis encompassed the number of wastewater treatment plants and individuals using those facilities, as well as the data concerning sewage sludge management in agriculture, land reclamation, use in cultivation of plants intended for composting, thermal processing, temporary storage at wastewater treatment plants, landfilling and other methods. Eurostat available data (2010, 2012-2014) were also included in the work [22].

The megagram $(\mathrm{Mg})$ is a unit of mass in the International System of Units (SI) that is defined as $10^{3} \mathrm{~kg}$ using the SI prefix system. In this work, a gigagram $(\mathrm{Gg})$ is a decimal multiple of the base unit of mass in the kilogram, where $1 \mathrm{Gg}=10^{9} \mathrm{~g}=10^{6} \mathrm{~kg}$ [23].

Due to the type of sewage treated in Poland, the treatment plants are distinguished into the following four stages [24]: 
1. Removal of solids,

2. Biological treatment,

3. Purification using biological and chemical methods (reduction of BOD5 and biogenic compounds),

4. Removal of residual pollutants.

One of the important processes for wastewater treatment is the mechanical-biological method. Figure 1 shows the wastewater treatment plant in the mechanical-biological system, considering the removal of biogenic compounds with mechanical sludge dewatering in Poland. The technological line includes the following devices: dense grates, vertical sand traps, averaging tanks, thickeners, dephosphatation chambers, nitrification chambers and secondary settling tanks [25].

\section{Results and discussion}

Figure 2 presents the number of sewage treatment plants in Poland, based on mechanical and biological treatment plants and those with improved biogenic compounds removal (IBCR). From 2009 to 2016, the number of municipal wastewater treatment plants increased by 100 facilities (3,153-3,253). While, in terms of wastewater treatment effectiveness, 131 new biological treatment plants and 13 plants with IBCR were launched. Within the period 2009-2016, 44 mechanical treatment plants were closed. It is noted that the increase concerned both general number of operating facilities and the inhabitants served. The trend related to systematic reduction of ineffective facilities to increase the proportion of more technologically advanced plants was the sign of consistent implementation of the NUWTP.

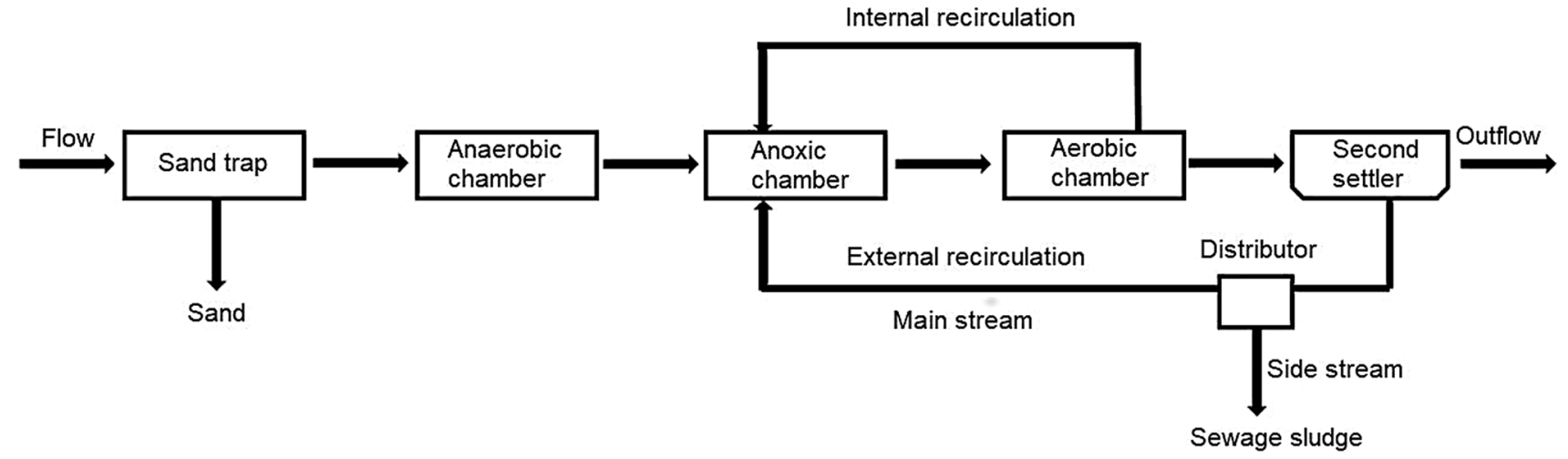

Fig. 1 The wastewater treatment plant in the mechanical-biological system, considering the removal of biogenic compounds with mechanical sludge dewatering in Poland (flows) [25]

Fig. 2 Number of wastewater treatment plants in Poland [21]

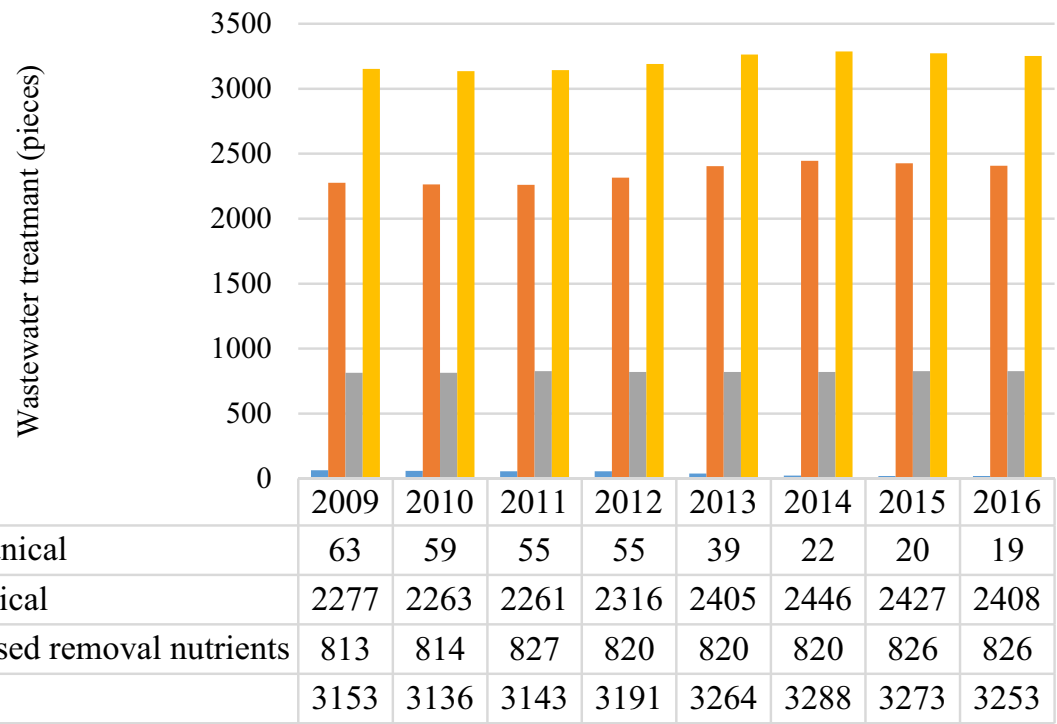


Figure 3 presents the percentage of inhabitants using wastewater treatment plants in urban and rural areas in Poland. Over the seven analysed years, a systematic increase in the percentage of inhabitants using wastewater treatment plants could be noticed, reaching 9\%. According to Werle et al. [26], an increasing number of sewage system connections is followed by the increase in the volume of sewage sludge produced. In Chile, sludge generation is one of the most important issues for sewage treatment plants [27]. A significant increase could be noticed since 2012, which was $4 \%$ in relation to the base year. The percentage of inhabitants using wastewater treatment plants in cities increased by $7 \%$. Similarly, in 2012, the largest increase (by $4 \%$ ) was also observed. In rural areas, the percentage of inhabitants using wastewater treatment plants increased by $14 \%$ in relation to the base year. In 2012, similarly highest increase by $6 \%$ in the percentage of inhabitants using wastewater treatment plants in relation to 2009 was observed. In 2016, it reached $41 \%$ (Fig. 3). However, this share was significantly lower, by as much as $54 \%$, in relation to the highest in 2016 for the inhabitants of the city using the sewage treatment plant. The sludge generated in wastewater treatment plant needs to be disposal not only due to legal requirements, but also for practical and aesthetic reasons [28]. In Poland, over the last few years, a general increase in production of sewage sludge has been observed. Figure 4 presents the volume of sewage sludge produced in the wastewater treatment process in Poland. According to the data of the Statistics Poland (SP), the dry matter $(\mathrm{dm})$ of sewage sludge reached $568.329 \mathrm{Gg}$ $\mathrm{dm}$ in 2016, which was approximately $49.000 \mathrm{Gg}$ more than in 2011. The volume decrease in generated sewage sludge occurred in 2010-2014 in the period from 2010 to 2014 in relation to 2009, which was related to the rate of increase of inhabitants using wastewater treatment services. This rate
Fig. 3 The percentage of inhabitants using sewage treatment plants in urban and rural areas [21]

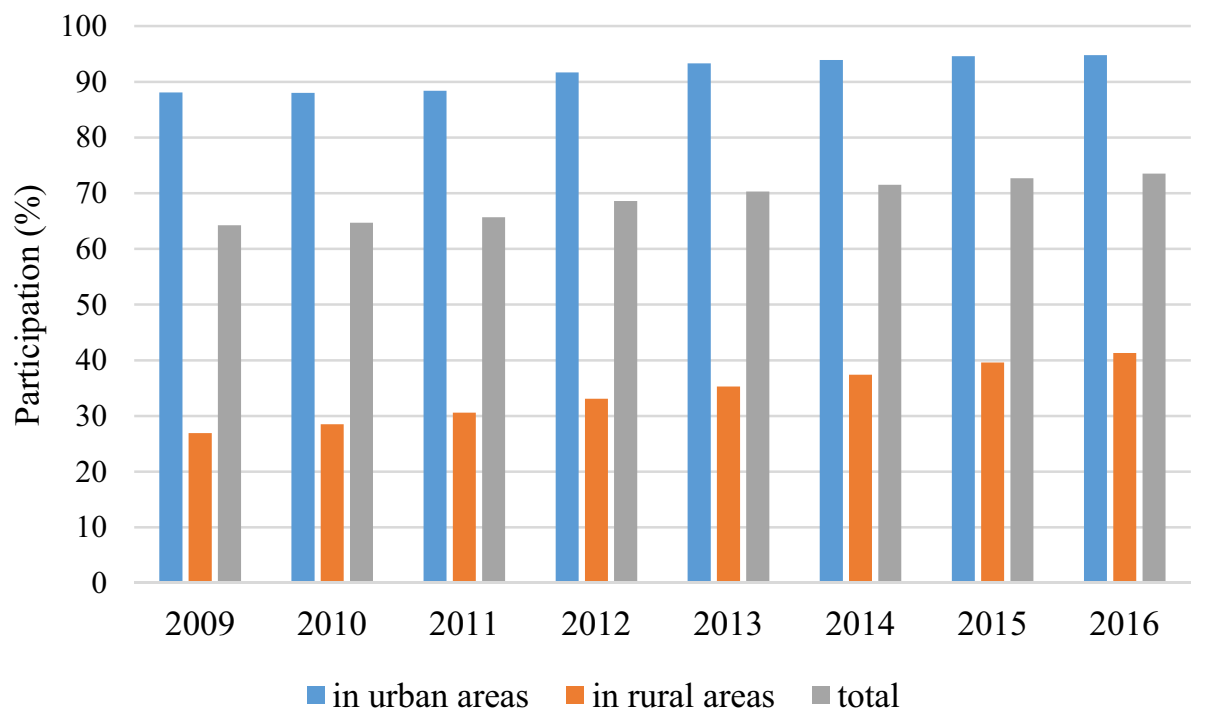

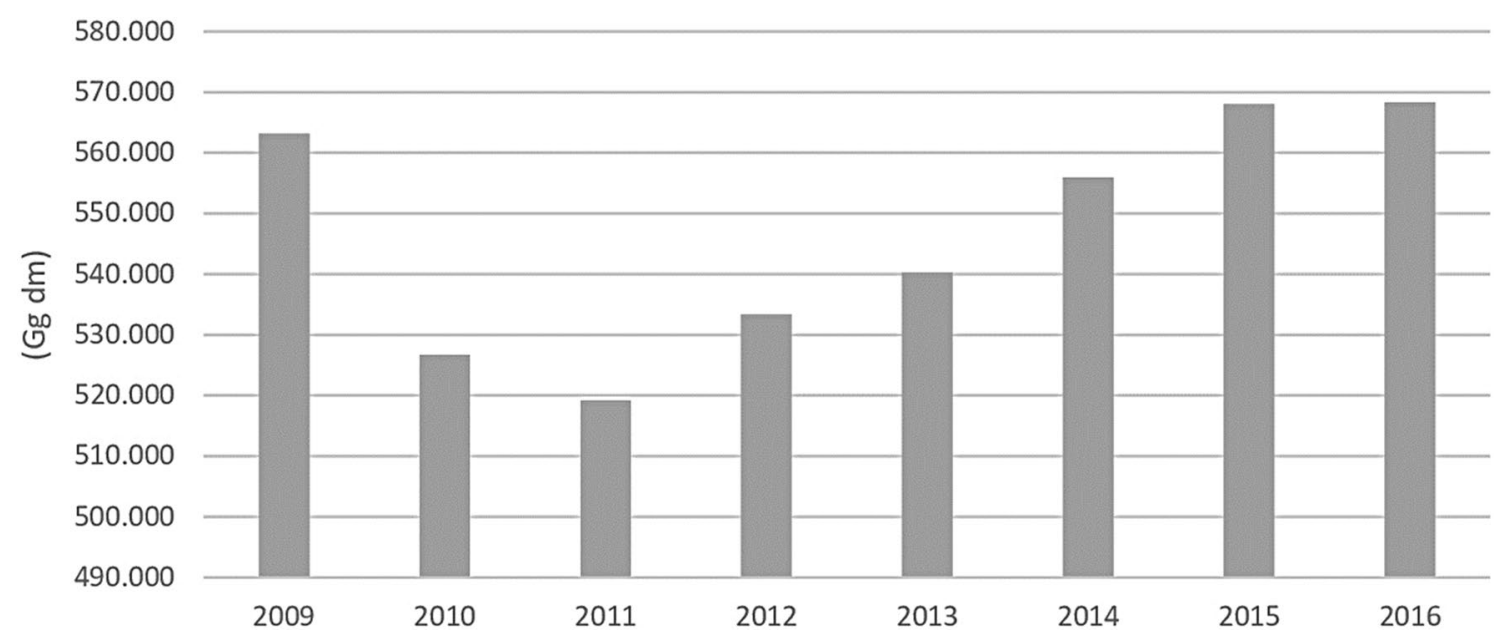

Fig. 4 Volume of sewage sludge produced in Poland in 2009-2016 [21] 
is lower than the rate of reduction of sludge weight as a result of sludge stabilisation. Large wastewater treatment plants recorded a decrease in the unitary production of sewage sludge [29]. Since 2015, an increase in the production of sewage sludge has been observed, which should be connected with the increase of sewage systems and the increase in wastewater volumes, as well as the improvement of efficiency of water purification processes in water treatment plants [30]. The increase in the volume of sewage sludge in Poland is determined by a number of factors related to the adjustment of the sewage sludge management to the European Union (EU) directives and, in particular, the 91/271/ EEC [6]. That increase of sewage sludge is related to the trend observed around the world, as indicated by Catallo and Comeaux [31]. But the decrease of sewage sludge amount between 2009 and 2010 of $6 \%$ was showed (Fig. 4). It may have been caused by reduction in the volume of water intake for industrial and municipal purposes due to the liquidation of unprofitable industrial plants and the introduction of modern technologies in the industry (with closed water circuit), as well as water saving by the population after the introduction of consumption metering [32].

The development of sewage systems, as well as modernisation of wastewater treatment plants to implement the high-efficiency technologies oriented on removal of biogenic compounds, or construction of new sewage treatment plants $[28,33]$.

Sewage sludge, when properly processed, i.e. compacted, stabilised, dehydrated, dried and incinerated, may be used in different ways. Table 1 presents the methods of usage of urban sewage sludge during the period 2009-2016.

A change in the sewage sludge management trends could be observed in the analysed period. These changes were mostly determined by legal regulations enforced in Poland, following the EU legislation. One of the most significant limitations is the prohibition in force since 1st January 2016, concerning the storage or composting of urban sewage sludge in landfill sites [34]. The prohibition of this type of activity is strictly connected to the 1999/31/EC directive [8]. It prohibits landfilling sewage sludge with gross calorific value exceeding $6 \mathrm{MJ} \mathrm{kg}^{-1}$ of dry matter.

With reference to the base year (2009), in the following years, a decrease in the volume of sewage sludge used for land reclamation for agricultural purposes may result from setting increasing requirements in terms of physical, chemical and biological sanitary properties as well as chemical and physical properties of soils in Poland. The total volume of sludge to be used for restoration purposes dropped by $57.700 \mathrm{Gg}$ of dry matter $(74 \%)$ from $77.834 \mathrm{Gg}$ of dry matter in 2009 to $20.075 \mathrm{Gg}$ of dry matter in 2016. A significant decrease was observed after 2012. In 2013, the volume of sewage sludge reached $29.407 \mathrm{Gg}$ of dry matter (62\% less). These results are reflected in the structure of sewage sludge management in Poland (Table 1).

In the National Waste Management Plan (NWMP) [35], one of the recommended methods of recovery is using sewage sludge for agricultural purposes. It has been assumed that until 2020 , approximately $30 \%$ of the volume of produced sewage sludge would be used in agriculture. Sludge with high content of organic substances, microelements and biogenic compounds has soil-forming and fertilising properties [36]. However, before introducing sludge into the ground, sanitary and chemical safety requirements must be met. The responsibility for proper usage of sewage sludge for agricultural purposes lies on the producer of the sludge [37]. Reusing sewage sludge in the ground and incineration are among the major practices approved by the EU-27 (all EU member states) to be implemented until 2020 [38].

Environmental and agricultural usage of sewage sludge is possible when proper legal requirements are met, concerning

Table 1 The methods of usage of urban sewage sludge during the period 2009-2016 [21]

\begin{tabular}{|c|c|c|c|c|c|c|c|c|c|}
\hline Directions of handling sewage sludge & Unit & 2009 & 2010 & 2011 & 2012 & 2013 & 2014 & 2015 & 2016 \\
\hline \multirow[t]{2}{*}{ Used in agriculture } & $(\mathrm{Gg})$ & 123.092 & 109.325 & 116.241 & 115.024 & 105.448 & 107.222 & 107.536 & 116.028 \\
\hline & $(\%)$ & 32 & 32 & 33 & 32 & 31 & 30 & 31 & 34 \\
\hline \multirow{2}{*}{$\begin{array}{l}\text { Used for the reclamation of land } \\
\text { including land for agricultural } \\
\text { purposes }\end{array}$} & $(\mathrm{Gg})$ & 77.834 & 54.279 & 54.386 & 50.280 & 29.407 & 21.961 & 19.167 & 20.075 \\
\hline & $(\%)$ & 20 & 16 & 16 & 14 & 9 & 6 & 5 & 6 \\
\hline \multirow{2}{*}{$\begin{array}{l}\text { Used for growing plants intended for } \\
\text { the production of compost }\end{array}$} & $(\mathrm{Gg})$ & 25.516 & 30.940 & 30.998 & 33.335 & 32.556 & 46.339 & 47.103 & 31.817 \\
\hline & $(\%)$ & 7 & 9 & 9 & 9 & 10 & 13 & 13 & 9 \\
\hline \multirow[t]{2}{*}{ Thermally transformed } & $(\mathrm{Gg})$ & 8.854 & 19.818 & 41.629 & 56.644 & 72.900 & 84.237 & 79.274 & 101.144 \\
\hline & $(\%)$ & 2 & 6 & 12 & 16 & 21 & 24 & 23 & 30 \\
\hline \multirow[t]{2}{*}{ Disposal } & $(\mathrm{Gg})$ & 81.622 & 58.917 & 51.447 & 46.796 & 31.369 & 31.503 & 40.458 & 20.666 \\
\hline & $(\%)$ & 21 & 17 & 15 & 13 & 9 & 9 & 12 & 6 \\
\hline \multirow[t]{2}{*}{ Temporary storage } & $(\mathrm{Gg})$ & 72.894 & 68.228 & 53.103 & 52.684 & 70.028 & 62.192 & 56.397 & 47.253 \\
\hline & $(\%)$ & 19 & 20 & 15 & 15 & 20 & 18 & 16 & 14 \\
\hline
\end{tabular}


the quality (content of pathogenic organisms and toxic substances), method of application and area of land in which it may be used. Sewage sludge that is characterised by high fertilising content may be used as a fertiliser or in reclamation of degraded land. However, before using sludge, the guidelines included in the resolution must be taken into account $[39,40]$. These regulations indicate allowable levels of heavy metals, number of living eggs of intestinal parasites, allowable doses of urban sewage sludge that may be used within a year per land area unit, etc. In 8 years, a decrease in agricultural usage of sewage sludge amounted to $7.064 \mathrm{Gg}$ of dry matter $(123.092 \mathrm{Gg}$ of dry matter in 2009 and $116.028 \mathrm{Gg}$ of dry matter in 2016) (Table 1). A significant problem related to environmental usage of urban sewage sludge is high content of heavy metals [41]. The lowest volume of sewage sludge used in agriculture was $105.448 \mathrm{Gg}$ of dry matter in 2013. After 2013, a slight increase in the amount of sewage sludge used in agriculture was observed. In 2016, the percentage of sewage sludge for agricultural usage increased to $8 \%$. In 2009, the weight of sludge used in cultivation of plants for compost production reached $25.516 \mathrm{Gg}$ of dry matter, which was $7 \%$ of the total usage of sewage sludge in Poland. In the following years, until 2012 and 2016, an increase up to 31 and 45\%, respectively, was observed. The year 2016 marked a decrease of $6 \%$, which means that the volume of sewage sludge used for compost production in the period from 2010 to 2013 was the same (Table 1). Hong et al. [3] demonstrated the possibility of using compost as a soil improver applicable in agriculture and horticulture, allowing the return of carbon, nitrogen, phosphorus and other elements to the soil. Assuming that in the year 2020, the use of sewage sludge in reclamation should be over 10\%, according to the NWMP [35], using the existing infrastructure in a correct way and following the requirements concerning the quality of compost should allow reaching the proper level, quite easily. In particular, this course is recommended for small and medium wastewater treatment plants.

In 2009, land reclamation, including agricultural lands, constituted $14 \%$, while in 2016 , only $4 \%$ of the total sludge usage. According to the data of the SP [42], the area of degraded lands to be recovered in Poland was stability, 63,000 hectares on average. Mining (extraction of coal and rocky materials) has the largest impact on formation of degraded lands [43]. While analysing the data, it must be pointed out that the extent of restoration of degraded lands is not satisfactory. In 2016, 1,400 hectares of land were restored (approximately $3.1 \%$ of the total area to be reclaimed) [37].

With regard to the changes in the structure of recovery and disposal of urban sewage sludge specified in the NWMP [35], it is expected that about $20 \%$ of sewage sludge would be used for land reclamation purposes in the year 2020 .
Considering the guidelines included in the NWMP [35], as well as the information concerning the unsatisfactory extent of land reclamation in Poland, it can be concluded that the trend related with land reclamation would be developed. Possible obstacles that most probably caused the decrease in popularity of sewage sludge usage for land reclamation purposes, including agricultural terrain, may be connected with legal conditions.

Temporary storage of sewage sludge at wastewater treatment plants (yards, lagoons, settling ponds) is related to landfilling or accumulation for transport and further use. The percentage of this method of sludge management generally decreased in the period from 2009 to 2016. In 2016, in relation to 2009 , the volume of temporarily stored sewage sludge dropped from $72.894 \mathrm{Gg}$ of dry matter to $47.253 \mathrm{Gg}$ of dry weight (25.641 Gg of dry weight less). A certain fluctuation was observed in 2014; after a period of decrease in the volume of stored sewage sludge, an increase in the amount was recorded in 2009 (constituting 13\% in the sewage sludge management structure). The following years marked a decrease of $8 \%$ in the sewage sludge management structure in 2016 (Table 1).

Thermal methods of urban sewage sludge disposal include incineration, co-incineration and so-called alternative methods such as: gasification, pyrolysis and wet oxidation. According to Pająk [44], the category of thermally processed sewage sludge refers to a collective participation of thermal processing methods such as drying, co-incineration, incineration in installations dedicated for sludge burning (so-called mono-incineration plants). Bień [45] has pointed out that sewage sludge drying is not a final neutralisation method, but rather a step towards it, and therefore it should be treated as a third stage of sewage sludge dehydration. The use of thermal methods of processing urban sewage sludge usually requires prior drying. In 2014, in Poland, there are 30 drying plants of thermal and sun drying of sewage sludge, with the yearly capacity of approximately $160.000 \mathrm{Gg}$ of dry matter [11]. Incineration of sewage sludge is conducted at 11 mono-incineration plants (seven fluidized bed and four grate incinerators). Co-incineration in cement factories is also developed. In 2014, yearly potential of cement factories is estimated at approximately $170.000 \mathrm{Gg}$ of dry mass [46]. Over the last few years, an evident development of thermal methods of sewage sludge processing has been observed. In 2009, the volume of thermally processed sewage sludge reached $8.854 \mathrm{Gg}$ of dry weight (Table 1). It was only $2 \%$ of the total sewage sludge management structure. In the following years, a gradual increase of participation of thermal methods in the sewage sludge management structure was noticeable, from $12 \%$ in 2012 to $24 \%$ in 2014 and $30 \%$ in 2016 (Table 1). Undoubtedly, that change was determined by launching another waste incineration plant. In Germany, the share of thermal methods of sewage sludge processing 
exceeded $50 \%$ in relation to other forms of their management [22].

In Poland, until mid-2010, there were only three monoincineration plants with the total capacity of $37.300 \mathrm{Gg}$ of dry matter. A noticeable change occurred in 2013, related to the increase in the number of waste incineration plants. As of 2013, there were 11 installations (mono-incineration plants) operating in large municipal sewage treatment plants. An alarming fact is that these systems do not use its potential $[46,47]$. In 2013, the volume of thermally processed urban sewage sludge reached $2.900 \mathrm{Gg}$ of dry mass (3\%), which was approximately $46 \%$ of the nominal capacity of the mono-incineration plants. Thermal processing of more than $30 \%$ of waste until 2020 is recommended in the NWMP [36]. The significant role of thermal processing of sewage sludge was also confirmed by Werther and Ogada [48]. The mentioned legal restrictions concerning the environmental usage of sewage sludge, as well as the prohibition of landfilling of unprocessed sludge, were in force since 1st January 2016, undoubtedly an impulse for intensification of activities was aimed at using the potential of thermal processing methods [47].

Due to high costs of sewage sludge utilisation by thermal post-processing, this solution is particularly applicable in large urban agglomerations [11]. Thermal processing is one of the best solutions, mainly because of maximum reduction of waste volume and its full hygienisation. The most common systems of sewage sludge thermal processing are those based on the fluidized bed incinerator technology [28]. Of course, sewage sludge must be dried before incineration, which entails additional costs. But after burning, the ash can be deposited at a local non-dangerous waste landfill site [49]. Lundin et al. [50] claimed that the costs of co-incineration of sewage sludge are much higher than the cost of its agricultural use. Landfilling of sewage sludge is one of the most cost-effective and simple methods of sewage sludge management from the point of view of sewage treatment plant operators. This process was legal in Poland until 1st January 2016. Sewage sludge was stored within the ground or on the surface (e.g. of a landfill site), mostly in a pre-stabilised, low-mineralised form, with high organic content. Since 2016 landfilling of unprocessed sewage sludge has been practically impossible, as this method of management does not fulfil the requirements specified in the resolution [35]. The document clearly prohibits landfilling sewage sludge with gross calorific value exceeding $6 \mathrm{MJ} \mathrm{kg}^{-1}$ of dry matter. Only processed sludge, in the form of ash or stabiliser may be used as alternative raw materials or additives to building materials [51]. The volume of sewage sludge stored at landfill sites in 2009 was $81.622 \mathrm{Gg}$ of dry weight. This method of sewage sludge disposal was used in Poland for $21 \%$ of sewage sludge volume, while in Croatia it was almost 100\% [22]. In the following period, from 2010 to 2016, a decrease related to a significant reduction in sewage sludge landfilling was observed. In 2016, in comparison with the base year 2009, the volume of sewage sludge was reduced to $22.666 \mathrm{Gg}$ of dry matter (decreased by $60.956 \mathrm{Gg}$ of dry matter) (Fig. 4). However, the participation of landfilling in the sewage sludge management structure was still 6\% in 2016 (Table 1). It should be noted that landfilling methods should be finally replaced with limited or thermal recycling methods or sewage sludge would have to lose the status of waste.

It should be noted that landfilling methods should be finally replaced with limited or thermal recycling methods or sewage sludge would need to lose the status of waste. This solution should be designated through the new strategies of eco-innovation for trends to meet the main concept of the European Commission's current strategy of 'reducing, reusing, recycling' understood as the most favourable waste management hierarchy [10]. In most cases, a shift in the effort towards the use of the energy value of sewage sludge is expected in legislation [52].

\section{Conclusions}

- The increase in the number of inhabitants using wastewater treatment plants in the analysed 8-years period was related to the adjustment of Polish legal regulations to the EU legislation.

- The growth of the sewage sludge volumes was caused by improved access to sewage systems and the efficiency of sewage treatment processes in wastewater treatment plants in Poland. A noticeable decrease in the amount of sewage sludge produced after 2009 was caused by the reduction in the number of inefficient sewage treatment plants and saving water by recipients.

- The agricultural use of sewage sludge was the highest average share of $32 \%$ in total weight, despite significant quality requirements of sludge for use in agriculture (content of pathogenic organisms and toxic substances).

- A significant increase (by 19\%) was observed in the use of thermal methods of sewage sludge neutralisation, which was determined by the launch of several new incineration plants, to improve the effectiveness of waste management, in accordance with the EU and Polish requirements.

- The significant decrease in the proportion of landfilled sewage sludge (reduction to $46 \%$ ), resulting from the enforcement of new requirements concerning, e.g. waste gross calorific value, should be considered positive. 
Acknowledgements The authors of the paper would like to thank authorities of State University of Applied Sciences in Nowy Sącz for financial support of its preparation.

Open Access This article is distributed under the terms of the Creative Commons Attribution 4.0 International License (http://creativeco mmons.org/licenses/by/4.0/), which permits unrestricted use, distribution, and reproduction in any medium, provided you give appropriate credit to the original author(s) and the source, provide a link to the Creative Commons license, and indicate if changes were made.

\section{References}

1. Malczewska B, Woźniak S, Jawecki B (2017) The advantages and disadvantages of composting of sewage sludge compared with thermal combustion—case study. Przegląd Naukowy Inżynieria i Kształtowanie Środowiska 26(1):125-135 (In polish)

2. Przewrocki P, Kulczycka J, Wzorek Z, Kowalski Z, Gorazda K, Jodko M (2004) Risk analysis of sewage sludge—Poland and EU comparative approach. Pol J Environ Stud 13(2):237-244

3. Hong J, Hong J, Otaki M, Jolliet O (2009) Environmental and economic life cycle assessment for sewage sludge treatment processes in Japan. Waste Manag 29:696-703

4. Inglezakis VJ, Zorpas AA, Karagiannidis A, Samaras P (2014) European Union legislation on sewage sludge management. Fresenius Environ Bull 23(2a):635-639

5. WFD E (2000) Directive 2000/60/EC of the European Parliament and of the Council establishing a framework for the Community action in the field of water policy. Joint text approved by the Conciliation Committee provided for in Article 251. https://www.eur. lex.europa.eu. Accessed 17 July 2018

6. Council Directive 91/271/EEC concerning urban waste-water treatment was adopted on 21 May 1991, http://eur-lex.europa.eu. Accessed 17 May 2018

7. Directive 2008/1/EC of the European Parliament and of the Council of 15 January 2008 concerning integrated pollution prevention and control. Off. J. Eur. Union, L., 24, http://eur-lex.europa.eu. Accessed 24 Jul 2019

8. Council Directive 99/31/EC of 26 April 1999 on the landfill of waste (Landfill Directive). Off. J. Eur. Communities L. 182, 16, http://eur-lex.europa.eu. Accessed 24 Jul 2019

9. Garrido-Baserba M, Molinos-Senante M, Abelleira-Pereira JM, Fdez-Güelfo LA, Poch M, Hernández-Sancho F (2015) Selecting sewage sludge treatment alternatives in modern wastewater treatment plants using environmental decision support systems. J Clean Prod 107:410-419

10. Kacprzak M, Neczaj E, Fijałkowski K, Grobelny A et al (2017) Sewage sludge disposal strategies for sustainable development. Environ Res 156:39-46

11. Bień J, Bień B (2015) Utilisation of municipal sewage sludge by thermal methods in the face of storage disallowing. Ecological Engineering 45(8):36-43 (In polish)

12. Pradel M, Reverdy AL, Richard M, Chabat L (2014) Environmental impacts of sewage sludge treatment and disposal routes: a life cycle assessment perspective. In: 4th European conference on sludge management, May 2014, Izmir, Turkey. 8 p hal-01094562

13. http://ec.europa.eu. Accessed 21 Jul 2019

14. Kouloumbis P, Rigas F, Mavridou A (2000) Environmental problems from the disposal of sewage sludge in Greece. Int $\mathrm{J}$ Environ Health Res 10:77-83

15. Stelmach S, Wasielewski R (2008) Co-combustion of dried sewage sludge and coal in a pulverized coal boiler. J Mater Cycles Waste Manag 10:110-115
16. The National Programme for Municipal Waste Water Treatment on 16 December 2003, http://mos.gov.pl. Accessed 18 May 2018

17. The Act of 14 December 2012 on waste (Journal of Laws 2013, item 21) http://sejm.gov.pl. Accessed 18 May 2018

18. Malerius $\mathrm{O}$, Werther $\mathbf{J}$ (2003) Modelling the adsorption of mercury in the flue gas of sewage sludge incineration. Chem Eng $\mathrm{J}$ 96:197-205

19. Samolada MC, Zabaniotou AA (2014) Comparative assessment of municipal sewage sludge incineration, gasification and pyrolysis for a sustainable sludge-to-energy management in Greece. Waste Manag 34:411-420

20. Valderrama C, Granados R, Cortina JL, Gasol CM, Guillem M, Josa A (2013) Comparative LCA of sewage sludge valorisation as both fuel and raw. J. Clean Prod 51:205-213

21. Statistics Poland (2009-2016) http://bdl.gov.pl. Accessed 18 May 2018

22. Eurostat (2010, 2012, 2013, 2014) http://ec.europa.eu. Accessed 19 May 2018

23. https://www.translatorscafe.com. Accessed 17 Jul 2019

24. Gołąb M, Nocoń W, Michalski R (2012) LAB Laboratoria, Aparat.2012. Hydrobotaniczne oczyszczalnie ścieków 17(4):610 (In polish)

25. Wałęga A, Plesiński K, Chmielowski K, Satora S (2010) Enhancement possibilities of nitrogen and phosphorus removal from sewage in the treatment plant in Lopuszna. Infrastruct Ecol Rural Areas (1):111-123 (In polish)

26. Werle S, Wilk RK (2010) A review of methods for the thermal utilization of sewage sludge: the Polish perspective. Renew Energy 35:1914-1919

27. Cartes J, Neumann P, Hospido A, Vidal G (2018) Life cycle assessment of management alternatives for sludge from sewage treatment plants in Chile: does advanced anaerobic digestion improve environmental performance compared to current practices? J Mater Cycles Waste Manag 20:1530-1540

28. Bień J, Neczaj E, Worwąg M, Grosser A, Nowak D, Milczarek M, Janik M (2011) Directions management of sludge in Poland after 2013. Inżynieria i Ochrona Środowiska 14(4):375-384

29. Wójtowicz A, Bieniowski M, Darul H, Jędrzejewski C (2013) Modelowe rozwiązania w gospodarce osadowej, Bydgoszcz: Bydgoski Dom Wydawniczy "Margrafsen” pp 1-500 (In polish)

30. Czekała A, Smurzyńska A, Kozłowski K, Brzoski M, Chełkowski D, Gajewska K (2017) Sewage sludge co-digestion as a way of recycling waste and producing energy. Problems Agric Eng 1(95):5-14 [In polish]

31. Catallo WJ, Comeaux JL (2008) Reductive hydrothermal treatment of sewage sludge. Waste Manag 28:2213-2219

32. Marszelewski W, Piasecki A (2014) Analysis of the development of wastewater infrastructure in Poland in ecological and economical aspects. Sci J Wars Univ Life Sci 11(60):127-137 [In polish]

33. Pająk T (2013) Thermal treatment as sustainable sewage sludge management. Environ Prot Eng 39(2):43-53

34. Regulation of the Minister of Economy of 16 July 2015 on the admission of waste for landfill (OJ 2015, item 1277), http:// sejm.gov.pl. Accessed 18 May 2018

35. Resolution No. 217 of the Council of Ministers of 24 December 2010 on National Waste Management Plan 2014 (M.P. 2010, No 101 item 1183), http://prawo.sejm.gov.pl/sap.nsf/DocDetails .xsp?id. Accessed 18 May 2018

36. Filkiewicz M (2015) Assessment of the possibilities of agricultural use of sewage sludge from wastewater treatment plants in Olecko. Ecol Eng 42:42-46 [In polish]

37. Sadecka Z, Myszograj S, Suchowska-Kisielewicz M (2011) Aspekty prawne przyrodniczego wykorzystania osadów ściekowych. Inżynieria Środowiska (24):5-17 (In polish) 
38. Kelessidis A, Stasinakis AS (2012) Comparative study of the methods used for treatment and final disposal of sewage sludge in European countries. Waste Manag 32:1186-1195

39. Regulation of the Minister of the Environment of 13 July 2010 on municipal sewage sludge (OJ 2010 No. 137, item 924), http:// sejm.gov.pl. Accessed 18 May 2018

40. Regulation of the Minister of the Environment of February 6 2015, regarding municipal sewage sludge (OJ 2015, item 257), http://sejm.gov.pl. Accessed 18 May 2018

41. Cieślik BM, Namieśnik J, Konieczka P (2015) Review of sewage sludge management: standards, regulations and analytical methods. J Clean Prod 90:1-15

42. Statistics Poland (2016) Environmental Protection. Statistical information and studies, http://stat.gov.pl/obszary-tematyczne/ srodowisko-energia/srodowisko/ochrona-srodowiska-2014,1,15. html. Accessed 18 Jun 2018

43. Gonda-Soroczyńska E, Kubicka H (2016) The importance of land reclamation and development in Poland in the context of environment protection. Infrastructure and Ecology of Rural Areas No I/1/2016, 163-175 (In polish)

44. Pająk T (2014) Thermal treatment of sewage sludge and the challenges of year 2016. Inżynieria i Ochrona Środowiska 17(3):363-376

45. Bień $\mathbf{J}$ (2012) Utilisation of sewage sludge in Poland by thermal method. Inżynieria i Ochrona Środowiska 15(4):439-449 (In polish)
46. Pająk T, Niesler J (2014) Successes and failures of thermal treatment of urban sewage sludge in Poland. Archiwum Gospodarki Odpadami i Ochrony Środowiska 6:79-86 (In polish)

47. Kijo-Kleczkowska A, Środa K, Kosowska-Golachowska M, Musiał T, Wolski K (2016) Combustion of pelleted sewage sludge with reference to coal and biomass. Fuel 170:141-160

48. Werther J, Ogada T (1999) Sewage sludge combustion. Prog Energy Combust Sci 25(1):55-116

49. Henclik A, Kulczycka J, Gorazda K, Wzorek Z (2014) Conditions of sewage sludge management in Poland and German. Inżynieria i Ochrona Środowiska 17(2):185-197 [In polish]

50. Lundin M, Olofsson M, Pettersson GJ, Zetterlund H (2004) Environmental and economic assessment of sewage sludge handling options. Resour Conserv Recycl 41:255-278

51. Hudziak G, Gorazda K, Wzorek Z (2012) Główne stosunki w zastosowaniu popiołów po termicznej obróbce osadów ściekowych. Czasopismo techniczne. Zeszyt 16:41-49 (In polish)

52. Christodoulou A, Stamatelatou K (2016) Overview of legislation on sewage sludge management in developed countries worldwide. Water Sci Technol 73(3):453-462

Publisher's Note Springer Nature remains neutral with regard to jurisdictional claims in published maps and institutional affiliations. 